\title{
Substitusi tepung kacang koro pedang (canavalia ensiformis (L.) DC.) Pada pie susu ditinjau dari sifat organoleptik, kandungan gizi dan unit cost
}

Clariza Arwi Nursalma ${ }^{1^{*}}$, Setyowati ${ }^{2}$, Almira Sitasari ${ }^{3}$

Jurusan Gizi, Poltekkes Kemenkes Yogyakarta, Jalan Tata Bumi No.3 Banyuraden, Sleman, 55143

${ }^{1}$ clarisa0602@gmail.com*; ${ }^{2}$ setyowati316@gmail.com; ${ }^{3}$ almira.sita@gmail.com

\begin{tabular}{ll}
\hline Informasi artikel: \\
\hline \\
Diterima & $: 2$ Maret 2021 \\
Revisi & $:$ Maret 2021 \\
Terbit & $: 25$ April 2021 \\
&
\end{tabular}

\section{Key word:}

Jack bean flour

Milk pie

Organoleptic

Nutritional content

Unit cost

\section{Kata kunci:}

Tepung kacang

koro

Pie susu

Organoleptik

Kandungan gizi

Biaya satuan

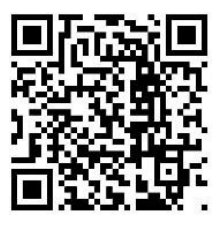

\begin{abstract}
ABSTRAK
Upaya untuk mengurangi ketergantungan terhadap tepung terigu adalah dengan menggunakan tepung terigu yang dibuat dari komoditas lokal. Tepung kacang koro dapat digunakan dalam pembuatan pie susu karena memiliki kandungan gizi yang tinggi sehingga dapat menunjang gizi masyarakat, serta memiliki nilai ekonomis yang tinggi. Metode penelitian yang digunakan adalah eksperimen murni. Data uji organoleptik dianalisis menggunakan uji K-Independen sampel (Kruskall-Wallis). Jika ada perbedaan, lanjutkan dengan Mann Whitney. Data kandungan gizi dianalisis menggunakan uji Anova sedangkan Data Unit Cost dianalisis secara deskriptif. Hasil uji organoleptik menunjukkan bahwa terdapat perbedaan tingkat kesukaan yang signifikan terhadap warna, aroma, rasa, dan tekstur pie susu dengan substitusi tepung kacang koro. Hasil uji kandungan gizi menunjukkan bahwa semakin tinggi substitusi tepung kacang koro maka semakin tinggi pula kandungan proteinnya. Hasil analisis biaya unit menunjukkan bahwa semakin banyak substitusi tepung kacang Jack maka semakin tinggi biaya unitnya. Substitusi tepung Jack Bean berpengaruh terhadap sifat organoleptik (warna, aroma, rasa, dan tekstur), kadar protein pie susu, dan biaya satuan pie susu. Namun tidak berpengaruh terhadap kandungan energi, lemak, dan karbohidrat pie susu.
\end{abstract}

Substitution of jack bean flour (Canavalia ensiformis (L.) DC.) on milk pie in terms of organoleptic properties, nutrition content, and unit cost

An effort to reduce dependence on wheat flour is to use wheat flour made from local commodities. Koro bean flour can be used in making milk pies because it has a high nutritional content so that it can support community nutrition, and has a high economic value. The research method used is pure experiment. Organoleptic test data were analyzed using the $\mathrm{K}$ Independent sample test (Kruskall-Wallis). If there is a difference, continue with Mann Whitney. The nutritional content data were analyzed using the Anova test while the Unit Cost data were analyzed descriptively. The results of the organoleptic test showed that there was a significant difference in the level of preference for the color, aroma, taste, and texture of the milk pie with the substitution of Jack bean flour. The results of the nutritional content test showed that the higher the substitution of koro bean flour, the higher the protein content. The result of unit cost analysis shows that the more substitutions of Jack bean flour, the higher the unit cost. The substitution of Jack Bean flour affects the organoleptic properties (color, aroma, taste, and texture), protein content of milk pie, and unit cost of milk pie. However, it has no effect on the energy, fat, and carbohydrate content of milk pie.

This is an open access article under the CC-BY-SA license. 


\section{Pendahuluan}

Saat ini variasi olahan di bidang pangan terus berkembang dan menghasilkan produkproduk olahan yang semakin beragam ${ }^{1}$. Namun, kreasi dalam pengolahan pie masih sedikit ${ }^{2}$. Pie adalah kue dengan dasar adonan pastel berisi buah atau krem, bagian atasnya dilapisi meringue, slagroom, atau pastry ${ }^{3}$. Tepung terigu merupakan struktur pokok dalam pembuatan pie $^{3}$. Salah satu kelemahan dari tepung terigu adalah tepung terigu berasal dari gandum yang merupakan komoditi impor*. Berdasarkan data Badan Pusat Statistik (BPS), impor gandum pada tahun 2019 mencapai 10,69 juta ton ${ }^{5}$. Produk pangan yang impor terus menerus tentunya dapat menjadi ancaman terhadap ketahanan pangan dalam negeri ${ }^{6}$. Upaya untuk mengurangi ketergantungan terhadap tepung terigu adalah dengan penggunaan tepung yang berbahan baku komoditas lokal, yaitu salah satunya tepung yang berasal dari kacang-kacangan. Salah satu kacang-kacangan yang mudah ditemui di Indonesia adalah kacang koro pedang7.

Kacang koro pedang merupakan tanaman yang termasuk dalam family Leguminoceae8. Kacang koro pedang mempunyai kandungan karbohidrat dan protein yang tinggi serta lemak yang lebih rendah . Dalam 100 gram kacang koro pedang mengandung energi 389 kkal, protein 27,4 gram, lemak 2,9. Adanya kandungan kimia yang cukup besar yaitu kandungan karbohidrat dan protein pada koro pedang membuka peluang baru untuk memanfaatkan koro pedang sebagai bahan baku produk Protein Rich Flour (PRF) atau tepung kaya protein'. Tepung kacang koro pedang digunakan sebagai produk perantara karena mempunyai kandungan gizi yang tinggi yaitu kandungan protein sehingga dapat menunjang gizi masyarakat, serta memiliki nilai ekonomi tinggi ${ }^{10}$.

Kandungan gizi yang sudah lengkap, pemanfaatan kacang koro pedang sebagai produk olahan belum begitu besar. Pemanfaatan kacang koro pedang belum begitu besar, karena koro pedang sulit untuk dikupas karena kulit koro cukup keras. Selain itu koro pedang juga mengandung senyawa toksik yaitu asam sianida atau HCN11. Kandungan sianida atau HCN pada kacang koro pedang dapat diminimalisir dengan beberapa perlakuan seperti perendaman, perebusan, pemanggangan, dan fermentasi sehingga menjadi produk yang aman untuk dikonsumsi ${ }^{7}$.

Tidak semua produk lokal dapat dijadikan tepung dikarenakan karakteristiknya. Bahan yang dapat dijadikan tepung untuk menggantikan tepung terigu harus mempunyai komponen yang kurang lebihnya sama seperti serealia, kacang-kacangan, dan sebagainya. Pie dapat dibuat dengan memanfaatkan tepung kacang koro pedang. Salah satu jenis pie yang dapat dibuat yaitu pie susu. Pie susu dipilih sebagai produk yang akan dibuat karena penelitian terkait substitusi tepung terigu dalam pembuatan pie susu belum banyak dilakukan di Indonesia. Pie susu diolah dengan memanfaatkan tepung kacang koro pedang agar dapat memvariasikan produk olahan kacang koro pedang, dapat menjadi alternative subtitusi tepung terigu, dan meningkatkan nilai ekonomis8. Selain itu diharapkan pie susu substitusi tepung kacang koro pedang dapat meningkatkan sifat organoleptic, kandungan gizi, dan dapat menurunkan unit cost. Penelitian ini bertujuan untuk mengetahui pengaruh substitusi tepung kacang koro pedang pada pie susu ditinjau dari sifat organoleptik, kandungan gizi, dan unit cost. 


\section{Metode}

Jenis penelitian ini adalah penelitian eksperimental murni dengan empat perlakuan, dua kali ulangan, dan satu unit percobaan. Dalam penelitian ini produk yang dihasilkan berupa pie susu dengan substitusi tepung kacang koro pedang yang akan diuji sifat organoleptic yang terdiri dari aspek warna, aroma, rasa, dan tekstur, kandungan gizi yang meliputi protein, lemak, karbohidrat, dan energi, serta perhitungan unit cost.

Perlakuan yang diberikan adalah substitusi tepung terigu:tepung kacang koro pedang dengan formula 100\%:0\%, 70\%:30\%, 50\%:50\%, dan 30\%:70\% dengan Rancangan Acak Sederhana (RAS). Adapun tahapan-tahapan dalam pembuatan pie susu dengan substitusi tepung kacang koro pedang sebagai berikut

Resep Standar Pie

1) Bahan-bahan yang digunakan dalam pembuatan pie susu tepung terigu Bahan Kulit Pie
a) Tepung Terigu Protein Sedang : 250 gram
b) Mentega
: 150 gram
c) Kuning Telur
: 2 butir
d) Garam
$: 1 / 4 \mathrm{sdt}$
e) Vanila Bubuk
$: 1 / 2 \mathrm{sdt}$
Bahan Isi
a) Susu Kental Manis
: 200 gram
b) Tepung Maizena
: 10 gram
c) Kuning Telur
: 2 butir
d) Vanili
$: 1 / 2 \mathrm{sdt}$

2) Cara membuat

1. Siapkan semua bahan dan timbang bahan sesuai resep

2. Campurkan semua bahan kulit dan aduk dengan garpu hingga teksturnya berbutir

3. Uleni adonan sampai merata

4. Olesi cetakan dengan margarin

5. Timbang adonan 20 gram kemudian cetak ke dalam cetakan pie lalu tusuk-tusuk dengan garpu

6. Campurkan semua bahan isi pie susu lalu aduk hingga merata dan saring

7. Tuang adonan isi kedalam cetakan yang sudah dilapisi adonan kulit

8. Panggang dalam oven selama 45 menit pada suhu $175^{\circ} \mathrm{C}$

9. Angkat pie susu yang sudah matang

Resep pie susu substitusi tepung kacang koro pedang

Bahan-bahan yang digunakan dalam pembuatan pie susu substitusi tepung kacang koro pedang yaitu:

Bahan Kulit Pie
a) Tepung Terigu Protein Sedang : Perlakuan A : 250 gram
Perlakuan B : 175 gram
Perlakuan C : 125 gram
Perlakuan D : 75 gram
b) Tepung Kacang Koro Pedang : Perlakuan A : 0 gram
Perlakuan B : 75 gram
Perlakuan C : 125 gram
Perlakuan D : 175 gram
c) Mentega
: 150 gram 

d) Kuning Telur
: 2 butir
e) Garam
$: 1 / 4 \mathrm{sdt}$
f) Vanila Bubuk
$: 1 / 2 \mathrm{sdt}$
Bahan Isi
a) Susu Kental Manis
: 200 gram
b) Tepung Maizena
: 10 gram
c) Kuning Telur
: 2 butir
d) Vanili
$: 1 / 2 \mathrm{sdt}$

Penelitian ini dilaksanakan pada bulan Februari 2021. Proses pembuatan pie susu, uji sifat organoleptik, dan analisis unit cost dilakukan di rumah peneliti yaitu di Jalan Durian Bajing, Kroya, Cilacap. Sedangkan uji kandungan gizi dilakukan di Laboratorium Analisa Chem-Mix Pratama, Bantul, Yogyakarta.

Panelis dalam penelitian ini yaitu panelis tidak terlatih. Panelis tidak terlatih merupakan sekelompok orang berkemampuan rata-rata yang tidak terlatih secara formal, tetapi mempunyai kemampuan untuk membedakan dan mengkomunikasikan reaksi dari penilaian organoleptic. Jumlah anggota panelis tidak terlatih berkisar antara 25 sampai 100 orang ${ }^{12}$. Dalam penelitian ini digunakan 30 orang panelis tidak terlatih yaitu masyarakat umum.

Analisis data sifat organoleptik dianalisis menggunakan Kruskal-Wallis jika ada perbedaan dilanjutkan dengan uji Mann-Whitney untuk mengetahui perbedaan antar sampel. Sedangkan untuk mengetahui kandungan karbohidrat diukur menggunakan metode spektrofotometri, kandungan protein dengan menggunakan metode Kjedahl, lemak diukur dengan menggunakan metode Soxlet (AOAC,1995), dan untuk kandungan energi didasarkan kandungan protein, lemak, dan karbohidrat yang diketahui, setelah diubah kedalam satuan energi kemudian jumlahkan. Hasil uji kandungan gizi dianalisis menggunakan uji Anova. Dan hasil perhitungan unit cost dianalisis secara deskriptif.

\section{Hasil dan Pembahasan}

Hasil

\section{A. Sifat Organoleptik}

Uji Organoleptik dilakukan untuk mengetahui tingkat kesukaan panelis terhadap warna, aroma, rasa, dan tekstur dari produk pie susu yang disajikan. Uji organoleptik dilakukan dengan panelis tidak terlatih sebanyak 30 orang yaitu masyarakat umum untuk menilai tingkat kesukaan terhadap produk pie susu dengan substitusi tepung kacang koro pedang. Uji organoleptik dilakukan sebanyak 2 kali ulangan. Metode yang digunakan dalam penilaian sifat organoleptik yaitu Uji Hedonik atau Hedonic Scale Test. Mean rank uji organoleptik pie susu dapat dilihat pada Tabel 1.

Tabel 1. Mean Rank Uji Organoleptik Pie Susu

\begin{tabular}{ccccc}
\hline \multirow{2}{*}{ Perlakuan } & \multicolumn{4}{c}{ Sifat Organoleptik } \\
& Warna & Aroma & Rasa & Tekstur \\
\hline A $(100 \%: 0 \%)$ & $157,92^{\mathrm{a}}$ & $164,01^{\mathrm{a}}$ & $166,32^{\mathrm{a}}$ & $124,13^{\mathrm{a}}$ \\
B $(70 \%: 30 \%)$ & $147,92^{\mathrm{a}}$ & $130,82^{\mathrm{b}}$ & $155,17^{\mathrm{a}}$ & $193,77^{\mathrm{b}}$ \\
C (50\%:50\%) & $115,48^{\mathrm{b}}$ & $95,97^{\mathrm{c}}$ & $95,59^{\mathrm{b}}$ & $105,40^{\mathrm{c}}$ \\
D (30\%:70\%) & $60,68^{\mathrm{c}}$ & $91,21^{\mathrm{c}}$ & $64,92^{\mathrm{c}}$ & $58,70^{\mathrm{d}}$ \\
P Value & 0,000 & 0,000 & 0,000 & 0,000 \\
\hline
\end{tabular}

Keterangan: angka probabilitas $<0,05$ menyatakan ada perbedaan yang nyata. Notasi huruf berbeda pada kolom yang sama menunjukan ada perbedaan yang nyata. 
Hasil dari uji Kruskal Wallis menunjukkan bahwa produk pie susu substitusi tepung kacang koro pedang pada tingkat kesukaan panelis ada perbedaan pada warna, aroma, rasa, dan tekstur. Adanya perbedaan pada warna, aroma, rasa, dan tekstur tersebut kemudian dilanjutkan dengan melakukan uji Mann-Whitney untuk mengetahui perbedaan antar dua variasi perlakuan.

1. Warna

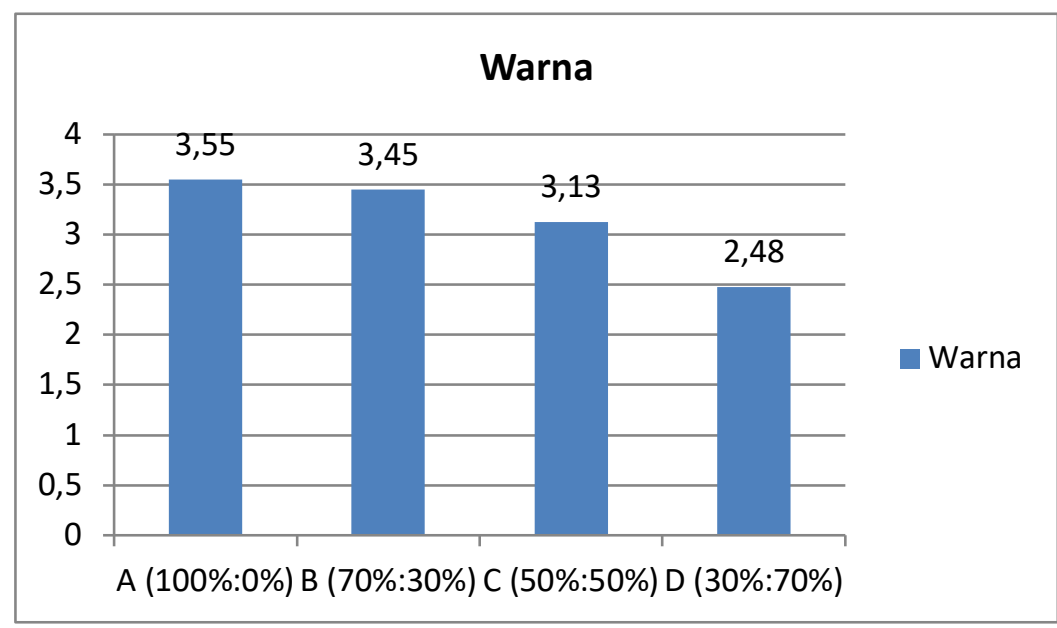

Gambar 1. Tingkat Kesukaan Panelis Terhadap Warna Pie Susu

Dari hasil uji hedonic yang dilakukan, diketahui bahwa skor rata-rata tingkat kesukaan panelis terhadap pie susu substitusi tepung kacang koro pedang dari aspek warna semakin menurun seiring bertambahnya jumlah substitusi tepung kacang koro pedang. Berdasarkan uji statistik dapat diketahui bahwa pada pie susu A dan B tidak ada perbedaan yang nyata. Namun pada perlakuan A dan B terdapat perbedaan yang nyata dengan perlakuan C dan D. Begitupun pada perlakuan $C$ dan $D$ memiliki notasi yang berbeda yang artinya terdapat perbedaan yang nyata.

2. Aroma

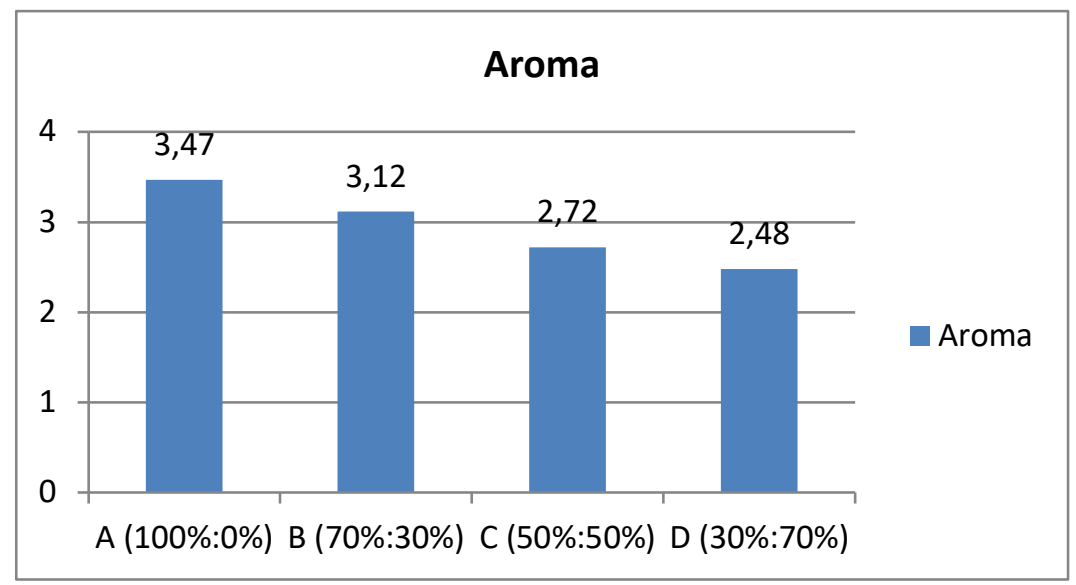

Gambar 2. Tingkat Kesukaan Panelis Terhadap Aroma Pie Susu

Dari hasil uji hedonic yang dilakukan, diketahui bahwa skor rata-rata tingkat kesukaan panelis terhadap pie susu substitusi tepung kacang koro pedang dari aspek aroma semakin menurun seiring bertambahnya jumlah substitusi tepung kacang koro pedang. Berdasarkan uji statistik dapat diketahui bahwa pada pie susu C dan D tidak ada perbedaan yang nyata. 
Namun perlakuan A dan B memiliki notasi yang berbeda yang artinya terdapat perbedaan yang nyata. Begitupun pada pie susu A dan B yang memiliki perbedaan yang nyata terhadap pie susu C dan D.

3. Rasa

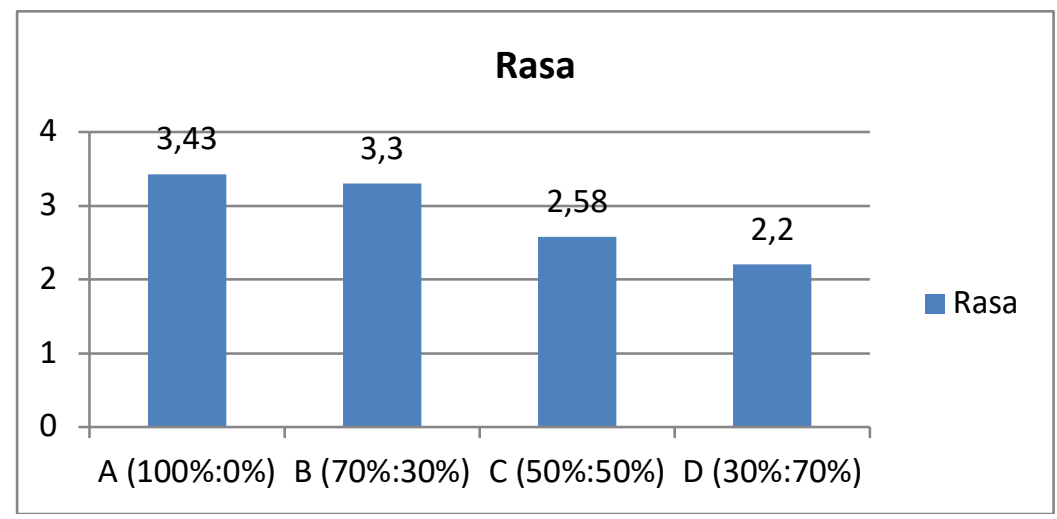

Gambar 3. Tingkat Kesukaan Panelis Terhadap Rasa Pie Susu

Dari hasil uji hedonic yang dilakukan, diketahui bahwa skor rata-rata tingkat kesukaan panelis terhadap pie susu substitusi tepung kacang koro pedang dari aspek rasa semakin menurun seiring bertambahnya jumlah substitusi tepung kacang koro pedang. Berdasarkan uji statistik dapat diketahui bahwa pada pie susu A dan B tidak ada perbedaan yang nyata. Namun pie susu A dan B terdapat perbedaan yang nyata terhadap pie susu C dan D.

4. Tekstur

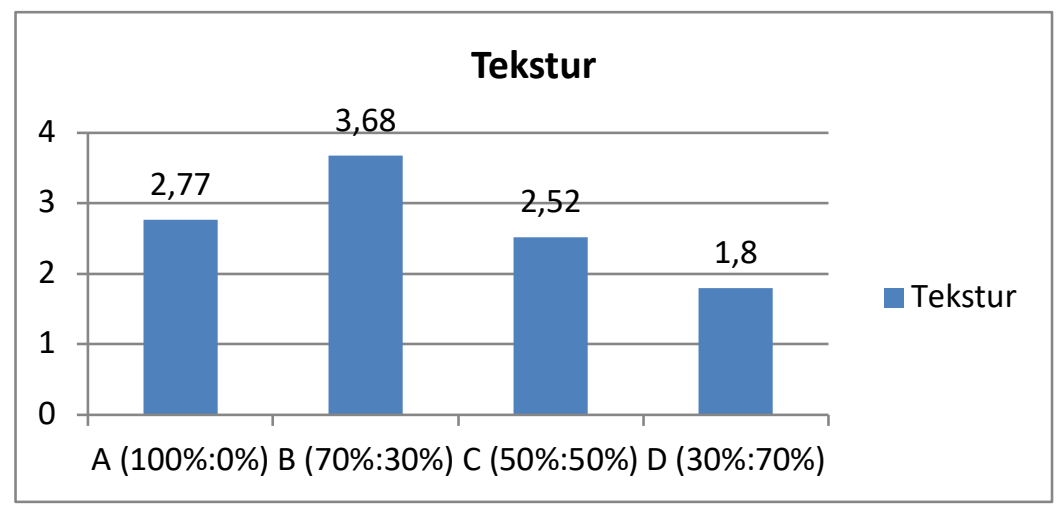

Gambar 4. Tingkat Kesukaan Panelis Terhadap Rasa Pie Susu

Dari hasil uji hedonic yang dilakukan, diketahui bahwa skor rata-rata tingkat kesukaan panelis terhadap pie susu substitusi tepung kacang koro pedang dari aspek tekstur tertinggi pada pie susu $\mathrm{B}(70 \%: 30 \%)$. Dari hasil uji statistic dapat diketahui bahwa terdapat perbedaan yang nyata pada pie susu A, B, C, dan D.

\section{B. Kandungan Gizi}

Analisis kandungan gizi dilakukan dengan tujuan untuk mengetahui kadar protein, lemak, karbohidrat, dan energi yang terdapat dalam 100g pie susu kelompok kontrol yang hanya menggunakan tepung terigu dan kelompok perlakuan dengan substitusi tepung kacang koro pedang. Hasil analisis kandungan gizi dapat dilihat pada Tabel 2. 
Tabel 2 . Hasil Analisis Perhitungan Kandungan Gizi Pie Susu

\begin{tabular}{cccc|c}
\hline Perlakuan & Protein (\%) & Lemak (\%) & Karbohidrat $(\%)$ & Energi (kkal) \\
\hline A (100\%:0\%) & $5,999^{\mathrm{a}}$ & $25,826^{\mathrm{a}}$ & $44,364^{\mathrm{b}}$ & $433,887^{\mathrm{a}}$ \\
\hline B (70\%:30\%) & $6,844^{\mathrm{a}}$ & $26,649^{\mathrm{a}}$ & $42,696^{\mathrm{ab}}$ & $438,006^{\mathrm{a}}$ \\
\hline C (50\%:50\%) & $11,207^{\mathrm{b}}$ & $24,619^{\mathrm{a}}$ & $41,157^{\mathrm{ab}}$ & $431,031^{\mathrm{a}}$ \\
\hline $\mathrm{D}(30 \%: 70 \%)$ & $12,816^{\mathrm{b}}$ & $25,033^{\mathrm{a}}$ & $37,199^{\mathrm{a}}$ & $425,363^{\mathrm{a}}$ \\
\hline $\mathrm{P}$ & 0,001 & 0,209 & 0,053 & 0,614
\end{tabular}

Keterangan: angka probabilitas $<0,05$ menyatakan ada perbedaan yang nyata. Notasi huruf berbeda pada kolom yang sama menunjukan ada perbedaan yang nyata.

\section{Protein}

Kadar protein pie susu meningkat seiring dengan meningkatnya proporsi substitusi tepung kacang koro pedang. Ada kecenderungan bahwa dengan semakin banyak substitusi tepung kacang koro pedang mampu meningkatkan kandungan protein dibandingkan dengan perlakuan kontrol (100\% tepung terigu:0\% tepung kacang koro pedang). Pada pie susu perlakuan A dan B memiliki notasi yang sama "a" artinya tidak ada perbedaan yang nyata. Begitupun dengan perlakuan $C$ dan $D$ memiliki notasi yang sama " $b$ " yang menunjukkan bahwa tidak ada perbedaan yang nyata. Namun pada perlakuan A dan B ada perbedaan yang nyata dengan perlakuan C dan D.

2. Lemak

Pada pie susu dengan perlakuan A, B, C, dan D memiliki notasi yang sama yang menunjukkan bahwa pada keempat perlakuan pie susu tidak ada perbedaan yang nyata terhadap kandungan lemak dengan $p$ value $>0,05$.

3. Karbohidrat

Kadar karbohidrat pie susu cenderung menurun seiring dengan meningkatnya substitusi tepung kacang koro pedang. Pada pie susu perlakuan B dan C memiliki notasi yang sama "ab" artinya tidak ada perbedaan yang nyata. Namun pada perlakuan B dan C ada perbedaan dengan perlakuan A dan D.

4. Energi

Kandungan energi pada pie susu diperoleh dari perhitungan kandungan protein, lemak, dan karbohidrat. Pada pie susu dengan perlakuan A, B, C, dan D memiliki notasi yang sama yang menunjukkan bahwa pada keempat perlakuan pie susu tidak ada perbedaan yang nyata terhadap kandungan energi dengan $p$ value $>0,05$.

C. Unit Cost

Unit Cost Pie susu berbeda pada setiap perlakuan. Perbedaan unit cost disebabkan adanya substitusi tepung kacang koro pedang. Perbandingan unit cost pie susu dengan empat perlakuan dapat dilihat pada Tabel 3.

Tabel 3. Perbandingan Unit Cost Pie Susu

\begin{tabular}{|c|c|c|c|c|c|}
\hline \multirow[b]{2}{*}{ Biaya } & \multirow{2}{*}{$\begin{array}{c}\% \\
\text { Harga }\end{array}$} & \multicolumn{4}{|c|}{ Perlakuan } \\
\hline & & $\begin{array}{c}\text { A } \\
(100 \%: 0 \%)\end{array}$ & $\begin{array}{c}\text { B } \\
(70 \%: 30 \%)\end{array}$ & $\begin{array}{c}C \\
(50 \%: 50 \%)\end{array}$ & $\begin{array}{c}\text { D } \\
(30 \%: 70 \%)\end{array}$ \\
\hline Food Cost & 40 & Rp 19.175 & Rp 19.165 & Rp 19.158 & Rp 19.152 \\
\hline Overhead Cost & 25 & $\operatorname{Rp} 11.984$ & $\operatorname{Rp} 11.978$ & Rp 11.974 & $\operatorname{Rp} 11.970$ \\
\hline Labor Cost & 15 & Rp 7.191 & $\operatorname{Rp} 7.187$ & Rp 7.184 & Rp 7.182 \\
\hline Profit & 20 & Rp 9.587 & Rp 9.583 & $\operatorname{Rp} 9.579$ & $\operatorname{Rp} 9.576$ \\
\hline Total & 100 & $\operatorname{Rp} 47.937$ & $\operatorname{Rp} 47.913$ & $\operatorname{Rp} 47.895$ & $\operatorname{Rp} 47.880$ \\
\hline Unit Cost & & $\operatorname{Rp} 1.997$ & $\operatorname{Rp} 1.996$ & $\operatorname{Rp} 1.996$ & $\operatorname{Rp} 1.995$ \\
\hline
\end{tabular}




\section{Pembahasan}

\section{A. Sifat Organoleptik}

Uji organoleptic merupakan cara pengujian dengan menggunakan indera manusia sebagai alat utama untuk pengukuran daya penerimaan terhadap produk. Pengujian organoleptic mempunyai peranan penting dalam penerapan mutu. ${ }^{11}$.

\section{Warna}

Warna merupakan salah satu parameter penting yang memengaruhi panelis dalam menerima dan menilai produk ${ }^{12}$. Produk pie susu yang dihasilkan dipengaruhi oleh persentase substitusi tepung kacang koro pedang yang dicampurkan dalam pembuatan adonan kulit pie susu. Hasil uji statistic yang telah dilakukan terhadap warna pada produk pie susu menunjukkan bahwa ada perbedaan yang signifikan antar produk pie susu yang dibuat. Semakin banyak substitusi tepung kacang koro pedang pada produk pie susu menyebabkan warna pie susu semakin gelap. Kandungan protein dalam tepung memungkinkan terjadinya perubahan warna pada kulit pie $^{12}$.

2. Aroma

Aroma merupakan salah satu parameter dalam penentuan kualitas suatu produk makanan. Bau (aroma) dari suatu produk dapat diamati baik dengan cara membau dan dengan merasakan. Produk pie susu dengan substitusi tepung kacang koro pedang yang paling disukai berdasarkan aromanya adalah produk pie susu pada perlakuan $\mathrm{B}(70 \%: 30 \%)$. Perbedaan tingkat kesukaan ini disebabkan karena aroma langu pada produk pie susu dengan substitusi tepung kacang koro pedang. Semakin tinggi substitusi tepung kacang koro pedang pada pie susu menyebabkan tingkat kesukaan panelis terhadap aroma pie susu semakin menurun. Bau langu pada pie susu disebabkan oleh adanya aktivitas enzim lipokginase yang terdapat pada tepung kacang koro pedang ${ }^{10}$.

3. Rasa

Produk pie susu dengan substitusi tepung kacang koro pedang yang disukai oleh panelis adalah produk pie susu dengan perlakuan $\mathrm{B}(70 \%: 30)$ karena pada produk pie susu ini memiliki rasa yang hampir sama dengan perlakuan $\mathrm{A}(100 \%: 0 \%)$ yang memiliki rasa manis atau normal. Semakin banyak substitusi tepung kacang koro pedang maka cenderung menurunkan tingkat kesukaan panelis dari segi rasa. Hal tersebut sangat dipengaruhi oleh rasa tepung kacang koro pedang yang khas, jumlah tambahan tepung terigu yang lebih rendah tidak dapat menutupi rasa khas tepung kacang koro pedang.

4. Tekstur

Tekstur bersifat kompleks dan terkait dengan struktur bahan yang terdiri dari tiga elemen yaitu mekanik (kekerasan, kekenyalan), geometric (berpasir, beremah) dan mouthfeel (berminyak, berair) ${ }^{13}$. Produk pie susu dengan substitusi tepung kacang koro pedang yang disukai oleh panelis adalah produk pie susu dengan perlakuan $\mathrm{B}(70 \%: 30)$. Sedangkan pie susu yang paling tidak disukai oleh panelis yaitu pie susu pada perlakuan $\mathrm{D}(30 \%: 70 \%)$, dikarenakan memiliki tekstur yang mudah rapuh ${ }^{14}$.

\section{B. Kandungan Gizi}

Variasi di dalam kandungan gizi penting karena berpengaruh terhadap pemenuhan zat gizi yang dibutuhkan. Hal ini menyebabkan analisis komposisi zat gizi pangan menjadi penting ${ }^{15}$. Zat gizi yang dianalisis yaitu diantaranya protein, lemak, karbohidrat, dan energi.

1. Protein

Kandungan protein dalam makanan tidak hanya dipengaruhi oleh jumlah bahan makanan yang ditambahkan, tetapi juga dipengaruhi oleh penggunaan suhu pada proses 
pengolahan. Berdasarkan hasil uji kadar protein dapat diketahui bahwa semakin banyak substitusi tepung kacang koro pedang pada pie susu maka kadar protein akan semakin tinggi. Sejalan dengan hasil penelitian Shabrina N, semakin banyaknya substitusi tepung kacang koro pedang semakin bertambah kadar protein pada roti tawar ${ }^{16}$. Hasil pie susu substitusi tepung kacang koro pedang jika dibandingkan dengan syarat mutu SNI 2973:2011 yang menyatakan bahwa kadar protein pie minimal 3\%60, maka kadar protein pie susu pada keempat perlakuan memenuhi syarat mutu pai karena lebih dari 3\% yaitu 5,999\%-12,816\%.

2. Lemak

Lemak adalah suatu zat yang kaya akan energi, berfungsi sebagai sumber energi yang utama untuk proses metabolisme tubuh. Berdasarkan hasil uji kadar lemak pada pie susu menunjukkan bahwa tidak ada perbedaan signifikan pada setiap kelompok perlakuan dengan substitusi tepung kacang koro pedang. Serupa dengan hasil penelitian Imawan dkk, yang menunjukkan bahwa perbedaan formula cookies tidak berpengaruh nyata terhadap nilai kadar lemak yang dihasilkan. Penggunaan tepung komposit (tepung uwi dan tepung koro pedang) yang semakin rendah akan mengakibatkan peningkatan kadar lemak cookies ${ }^{17}$. Hasil pie susu dengan substitusi tepung kacang koro pedang jika dibandingkan dengan syarat mutu SNI 2973:2011 yang menyatakan bahwa kadar lemak pie minimal 9,5\%. Hasil kadar lemak pada pie susu dengan empat perlakuan memenuhi syarat mutu pai ${ }^{18}$.

3. Karbohidrat

Karbohidrat mempunyai peranan penting dalam menentukkan karakteristik bahan makanan seperti rasa, warna, dan tekstur. Hasil uji statistic menunjukkan bahwa tidak ada perbedaan yang signifikan pada setiap kelompok perlakuan dengan substitusi tepung kacang koro pedang. Hal tersebut sejalan dengan penelitian yang dilakukan oleh Imawan,dkk yang menunjukkan bahwa hasil dari kandungan karbohidrat setiap formula cookies komposit (tepung uwi dan tepung koro pedang tidak berbeda nyata ${ }^{17}$.

4. Energi

Energi merupakan salah satu hasil metabolism karbohidrat, protein dan lemak. Energi berfungsi sebagai zat tenaga untuk metabolisme. Hasil pie susu dengan substitusi tepung kacang koro pedang jika dibandingkan dengan syarat mutu SNI 2973:2011 yang menyatakan bahwa kadar energi pie minimal 400 kkal per 100 gram. Hasil kadar energi pada pie susu dengan empat perlakuan memenuhi syarat mutu pie karena lebih dari 400 kkal yaitu 425,363$438,006 \mathrm{kkal}^{19}$.

\section{Unit Cost}

Unit cost atau biaya satuan yang dikeluarkan untuk menghasilkan satu produk, dan merupakan biaya rata-rata hasil perhitungan dari biaya total dibagi sejumlah biaya produksi (bahan, SDM, dan overhead) ${ }^{20}$.

Harga jual tertinggi pie susu yaitu pada pie susu dengan perlakuan $\mathrm{A}(100 \%: 0 \%)$ memiliki harga jual Rp 1.997 per buah. Sedangkan harga pie susu terendah yaitu pada pie susu dengan perlakuan $\mathrm{D}(30 \%: 70 \%)$ yang memiliki harga jual Rp 1.995 per buah. Produk pie susu dengan substitusi tepung kacang koro pedang yang disukai oleh panelis secara keseluruhan yaitu perlakuan B(70\%:30\%) memiliki unit cost sebesar Rp1996. Hal tersebut terjadi karena pada pembuatan pie susu, tepung kacang koro pedang diproduksi sendiri serta bahan baku berupa kacang koro pedang diperoleh dari petani langsung yaitu dari UKM Damar Sindoro Sumbing Kab. Temanggung sehingga harga tepung koro pedang lebih rendah. 


\section{Kesimpulan}

Berdasarkan hasil penelitian dapat disimpulkan sebagai berikut: substitusi tepung kacang koro pedang dengan perlakuan $\mathrm{B}(70 \%: 30 \%)$ berpengaruh terhadap sifat organoleptik pie susu (warna, aroma, rasa, dan tekstur), kandungan protein pie susu, dan unit cost pie susu. Namun tidak berpengaruh terhadap kandungan energi, lemak, dan karbohidrat pie susu. Pie susu dengan perlakuan B (70\%:30\%) direkomendasikan untuk dikembangkan karena memiliki tingkat kesukaan terhadap tekstur yang lebih tinggi, kandungan protein yang lebih tinggi, serta unit cost yang lebih rendah.

\section{Reference}

1. Mustika D. Pengaruh Substitusi Tepung Talas Terhadap Kualitas Kulit Pie [Skripsi].; 2017.

2. Pratiwi YS. dan BK. Pengaruh Konsentrasi Dan Jenis Tepung Growol Terhadap Sifat Fisik, Kimia Dan Tingkat Kesukaan Pie Coklat [Skripsi].; 2018.

3. Faridah, A D. Patiseri Jilid 12 3.; 2008.

4. Hermadayanti YT. Kajian Perbandingan Tepung Kacang Koro Pedang (Canavalia Ensiformis) Dengan Tepung Terigu Dan Jenis Gula Pada Karakteristik Cookies Green Tea [Skripsi].; 2017.

5. Statistik BP. Data Impor Biji Gandum dan Meslin Menurut Negara Asal Utama 2010-2019. Published online 2019.

6. Winarno FG. Kimia Pangan Dan Gizi. Edisi Ke Dua. Gramedia Pustaka Utama; 1997.

7. Hearsa AA dan E. Analisis Kualitas Kulit Pie Dengan Substitusi Tepung Kacang Hijau. J Kapita Sel Geogr. 2.2 (2019):7-14.

8. Setyaningsih, D., Anton A. dan MPS. Sensori Untuk Industri Pangan Dan Argo. IPB Press; 2010.

9. Chayati I. Bahan Ajar Pengujian Bahan Pangan Prodi Teknik Boga UNY. http://staffnew.uny.ac.id/upload/132300107/pendidikan/bab-02-pengujian-bahanpangan.pdf (Diakses tanggal 4 Juni 2020)

10. Shabrina N. Pengaruh Subtitusi Tepung Terigu Dengan Tepung Kacang Koro Pedang (Canavalia Ensiformis L) Dan Lama Fermentasi Terhadap Karakteristik Roti Tawar [Skripsi].

11. Viani DH. Karakteristik Fisik Dan Mutu Hedonik Biskuit Hasil Substitusi Tepung Terigu Dengan Tepung Pati Koro Pedang [Skripsi].; 2017.

12. Nurohman SH. Kajian Kandungan Protein Tepung Kacang Koro Pedang (Canavalia Ensiformis) Yang Dikemas LDPE (Low Density Polyethylene) Selama Penyimpanan Menggunakan Regresi Linier Sederhana [Skripsi].; 2016.

13. Putri DY. Pemanfaatan Tepung Kacang Koro Pedang Pada Pembuatan Pionie Jack Bean [Skripsi].; 2018.

14. Agustia FC. Formulasi Flake Mohiro dari Mocaf-Beras Hitam dengan Penambahan Kacang Koro Pedang sebagai Alternatif Sarapan Tinggi Protein dan Serat. J Apl Teknol Pangan. 2018;8.4 (2019):130-136.

15. Shfali Dhingra SJ. Organoleptic and nutritional evaluation of wheat breads supplemented with soybean and barley flour. Food Chem. 2007;77 (2001):479-488.

16. Aini LN. Pengaruh Substitusi Tepung Koro Pedang (Canavalia Ensiformis L) Terhadap Tingkat Pengembangan Dan Daya Terima Donat [Skripsi].; 2016.

17. Yuniar E. Kajian Perbandingan Tepung Kacang Koro Pedang (Canavalia Ensiformis) Dengan Tepung Terigu Dan Konsentrasi Kuning Telur Terhadap Karakteristik Cookies Koro [Skripsi].; 2016.

18. Susanti, L. H, Yoga Pratama dan N. Pengaruh Formulasi Tepung Kacang Koro Pedang Fraksi Protein, Fraksi Serat, Dan Tepung Maizena Terhadap Sifat Fisik, Kimia, Dan Organoleptik Bakso Analog. [Skripsi].; 2017. 
19. Imawan, Moh Luthfi R. Baskara Katri Anandito, and Siswanti Siswanti. Karakteristik Fisik, Kimia Dan Sensori Cookies Berbahan Dasar Tepung Komposit Uwi (Dioscorea alata), Koro Pedang (Canavalia ensiformis) Dan Tepung Terigu. J Teknol Has Pertan. 12.1:18-28.

20. Ayustaningwarno F. Teknologi Pangan Teori Praktis Dan Aplikasi. Graha Ilmu; 2014. 